\title{
Lipertance - jeden krok v léčbě kardiovaskulárního rizika, aneb nikdy to nebylo jednodušší
}

Na XXIII. kongresu České internistické společnosti ČLS JEP byla představena první fixní trojkombinace pro léčbu hypertenze a dyslipidemie Lipertance ${ }^{\circledR}$. Lipertance ${ }^{\circledR}$ obsahuje atorvastatin, inhibitor angiotensin-konvertujícího enzymu (ACEI) perindopril arginin a blokátor kalciových kanálů (BKK) amlodipin. Umožňuje $v$ jediném kroku - při podání jedné tablety denně - kompenzovat dva často souběžně se vyskytující kardiovaskulární (KV) rizikové faktory s předpokladem lepší adherence nemocných $k$ léčbě. $K$ dispozici je $v$ pěti rưzných kombinacích dávek pro individuální přistup $k$ léčbè. Tuto novou fixní kombinaci představili účastníkům kongresu doc. MUDr. Michal Vrablik, Ph.D. (III. interní klinika 1. LF UK a VFN v Praze), prof. MUDr. Richard Češka, CSc. (III. interní klinika 1. LF UK a VFN v Praze) a prof. MUDr. Aleš Linhart, DrSc. (II. interní klinika kardiologie a angiologie 1. LF UK a VFN v Praze). Obsah jejich sdělení bychom vám rádi přibližili i touto cestou.

\section{Hypertenze a dyslipidemie: dvě diagnózy -} jedno řešení

\section{Body k zapamatování}

- Současný výskyt hypertenze a dyslipidemie akceleruje KV riziko.

- Kontroly obou rizikových faktorů je dosahováno pouze $u$ jedné třetiny pacientů.

- Nízkou adherenci k léčbě Ize zvýšit podáváním fixních kombinací s dávkováním jedenkrát denně.

- Nová fixní kombinace atorvastatin/perindopril/ amlodipin umožňuje léčbu dvou rizikových faktorů s účinností doloženou u volných kombinací.

Jak zdůraznil doc. Vrablike, nejméně každý druhý hypertonik na světě trpí také dyslipidemií [1]. Př́tomnost hypercholesterolemie u pacientů s hypertenzí akceleruje riziko rozvoje $\mathrm{KV}$ onemocnění [2]. Toto riziko pak dále exponenciálně stoupá kumulací dalších rizikových faktorů, jako je diabetes mellitus, obezita či kouření [3]. Již dlouho je znám prínos multifaktoriálního př́stupu v prevenci KV rizika. Léčba dyslipidemie a hypertenze znamená v rámci intervence jednotlivých rizikových faktorů největší prínos v prevenci KV prríhod [4]. Přesto $70 \%$ pacientů léčených pro obě diagnózy nedosahuje kontroly obou těchto rizikových faktorů [5]. Ve studii EUROASPIRE I-IV nedosáhly kontroly $\mathrm{LDL}$ cholesterolu $(<1,8 \mathrm{mmol} / \mathrm{l})$ více než tři čtvrtiny českých pacientů se stabilní ICHS a asi u 50 \% těchto nemocných nebylo dosaženo adekvátní kontroly TK [6]. Důvodem může být terapeutická inercie nebo nízká adherence pacientů $\mathrm{k}$ léčbě. Bylo zjištěno, že polovina hypertoniků ve věku 40-59 let přestane užívat antihypertenzní léčbu do jednoho roku [7]. Nepokračování v léčbě vede $k$ nárůstu výskytu cévních mozkových príhod (CMP) o $28 \%$ a infarktu myokardu (IM) o $15 \%$ [8]. Naopak dobrá adherence $\mathrm{k}$ hypolipidemické a antihypertenzní léčbě výskyt KV přihod snižuje [9]. Adherenci k léčbě Ize zvýšit rádnou edukací pacientů, současným zahájením terapie hypertenze a dyslipidemie [10], podáváním fixní kombi- nace [11] a dávkováním jedenkrát denně. Z hlediska adherence se jako nejvýhodnější ukazuje podávání ráno. Podávání moderních statinů, jako je např. atorvastatin, v ranních hodinách navíc není, navzdory vyskytujícímu se přesvědčení, spojeno s nižší účinností. Změny koncentrací celkového cholesterolu, LDL cholesterolu, triglyceridů i HDL cholesterolu jsou stejné, bez ohledu na dobu užití atorvastatinu [12].

Př́nos volné kombinace atorvastatinu, perindoprilu a amlodipinu dokládá řada studií. Přidání kombinace perindopril/amlodipin $\mathrm{k}$ léčbě statinem $\mathrm{v}$ analýze podskupin studie PERSPECTIVA zajistilo kontrolu TK u $73 \%$ pacientů $s$ nově zjištěnou hypertenzí nebo hypertenzí nekompenzovanou dosavadní terapií [13]. Ve studii ASCOT-LLA vedla trojkombinace perindopril/amlodipin/atorvastatin ke snížení LDL cholesterolu o 1,21 mmol// [14]. Synergické působení těchto tři látek dokládají i další výsledky této studie, kdy při porovnání s kombinací atorvastatin/atenolol/thiazidové diuretikum snížily riziko nefatálního IM a fatální ICHS o 53 \% vs. 16 \% [15]. Ve studii EUROPA znamenalo přidání perindoprilu $\mathrm{k}$ hypolipidemické léčbě a amlodipinu snížení celkové mortality o $58 \%$ a mortality z KV př́čin o $71 \%$ (obr. 1) [16].

Kombinace atorvastatin/perindopril arginin/amlodipin bude nyní dostupná v jediné tabletě jako Lipertance ${ }^{\circledR}$ v pěti dávkových variantách (tabulka 1). Díky tomu Ize tuto fixní kombinaci použít v iniciální léčbě hypertoniků s dyslipidemií i k pokračování léčby s možností titrace dávky. Lipertance ${ }^{\circledast}$ nabízí osvědčené účinné látky podložené klinickými studiemi a ověřené mnohaletými zkušenostmi z klinické praxe. Slibuje zlepšení adherence nad rámec fixních kombinací antihypertenziv.

\section{Mýty a fakta o statinech}

Body k zapamatování

- Statiny prokazatelně snižují výskyt KV příhod, mortalitu z KV př́čin i celkovou mortalitu. 


\section{Atorvastatin/perindopril arginin/amlodipin u pacientů s ICHS bez srdečního selhání}

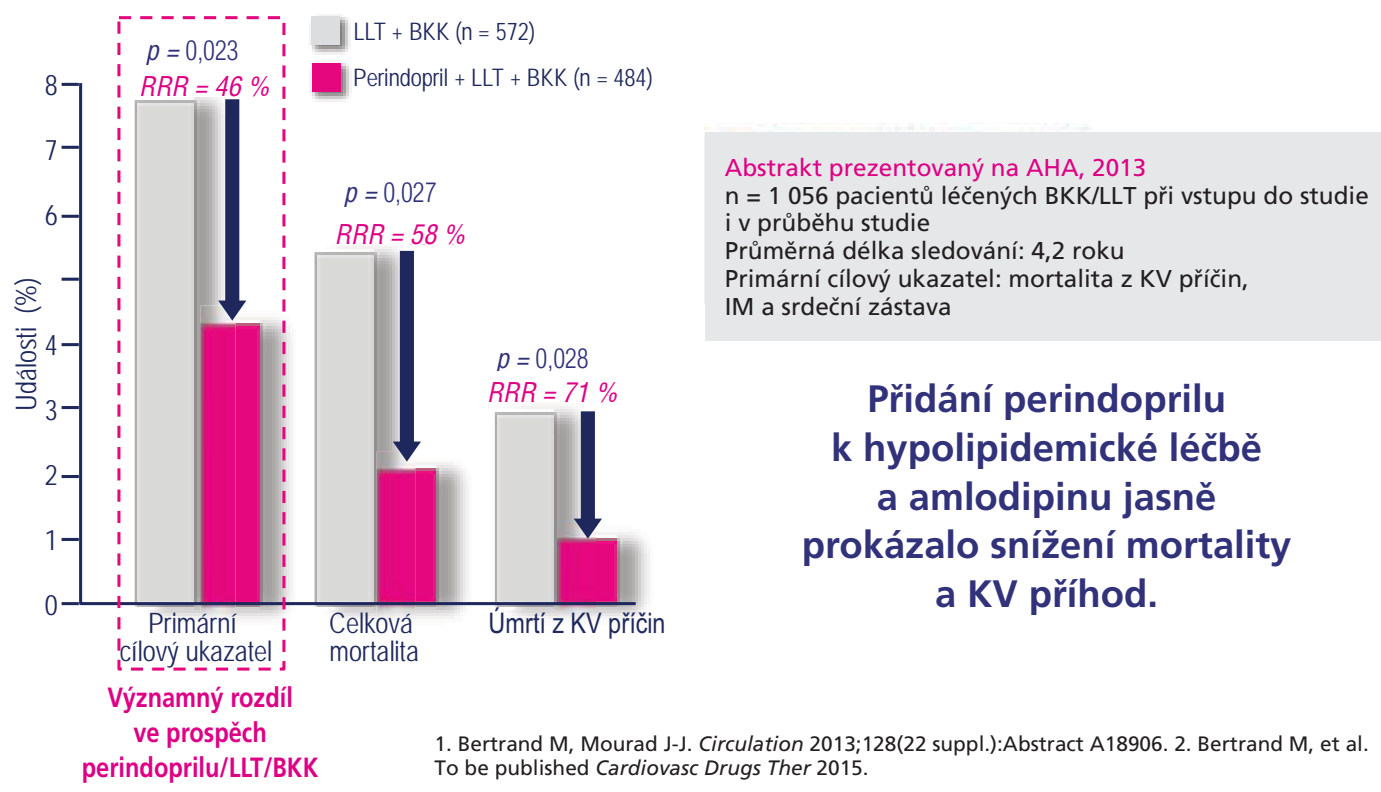

Obr. 1 - Synergické působení perindoprilu, amlodipinu a statinu v KV prevenci ve studii EUROPA

BKK - blokátory kalciových kanálů; IM - infarkt myokardu; KV - kardiovaskulární; LLT - lipid-lowering therapy; RRR - pokles relativního rizika.

- Nežádoucí účinky statinů jsou zbytečně přeceňovány.

- Př́nosem je intenzivní hypolipidemická léčba s nízkými cílovými hodnotami, protože každému snížení LDL cholesterolu o $1 \mathrm{mmol} / \mathrm{l}$ odpovídá pokles KV rizika o $21 \%$.

Prof. Češka připomněl, že cílem léčby dyslipoproteinemií je optimalizace lipidového spektra, dosahování cílových hodnot a princip „čím níže, tím lépe". Primárním cílovým ukazatelem je snížení LDL cholesterolu, kde lék první volby představují statiny. Již studie 4S [17] v roce 1994 prokázala rychlé a setrvalé snížení LDL cholesterolu o $35 \%$ při léčbě simvastatinem spolu s poklesem triglyceridů o $25 \%$, KV rizika o $42 \%$ a celkové mortality o $30 \%$. Zavedení statinů $v$ 90. letech vedlo $\mathrm{k}$ výraznému poklesu mortality u nemocných s familiární hypercholesterolemií. Pokles mortality z KV přícin i celkové mortality potvrdily i dlouhodobé (20leté) výsledky studie WOSCOPS s pravastatinem. Snížení výskytu velkých KV příhod při léčbě simvastatinem bylo prokázáno ve studii HPS u všech podskupiny pacientů (s ICHS, hypertenzí, diabetem i jinými KV chorobami) [18]. U diabetiků snížil atorvastatin ve studii CARDS relativní riziko KV príhod o $37 \%$, ve studii 4S [19] významně snížil celkovou i mortalitu z KV příčin, výskyt velkých KV příhod i revaskularizace. Metaanalýza 26 studií se statiny ukázala významné snížení rizika CMP o 21 $\%$ [20]. Při porovnání $10 \mathrm{mg}$ a $80 \mathrm{mg}$ atorvastatinu u pacientů s ICHS ve studii TNT bylo zjištěno snížení relativního rizika KV příhod o 22 \% při podávání vyšší dávky [21].

I přes tento obrovský prínos statinů je někdy až nadměrná pozornost věnována jejich nežádoucím účinkưm. Jde zejména o svalové obtíže, hepatotoxicitu a diabetogenní účinky. Svalové symptomy při léčbě statiny Ize rozdělit na myalgie bez zvýšení kreatinkinázy (CK) (častý výskyt), myositidu se zvýšením CK < 10x horní limit normy (ULN) (neznámý výskyt) a rhabdomyolýzu se zvýšením CK > 10x ULN (vzácný výskyt) [22]. Celkově hlásilo svalové příznaky 10 \% pacientů, z nichž ovšem jen u 30 \% vedly k vysazení léčby (celkem u $3 \%$ pacientů) [23]. Pokud se týká hepatotoxicity, byla doložena zvýšená aktivita transamináz se stoupající dávkou statinů. Při nejvyšší dávce atorvastatinu 80 mg má zvýšenou aktivitu transamináz pouze 2,3 \% pacientů [24]. Léčba statiny proto ani nevyžaduje sledování jaterních funkcí. U statinů bylo zjištěno zvýšení rizika diabetu o $9 \%$. Jedná se ale o pacienty starší 60 let, často s metabolickým syndromem a pozitivní rodinnou anamnézou [25]. Počet pacientů, které musíme léčit statiny, abychom u jednoho pacienta vyvolali diabetes (NNH), je 250.

Tabulka 1 - Dávkové varianty fixní kombinace atorvastatin/perindopril arginin/amlodipin - Lipertance ${ }^{\circledR}$ [42]

\begin{tabular}{l|l|l|l}
\hline Lipertance $10 \mathrm{mg} / 5 \mathrm{mg} / 5 \mathrm{mg}$ & Atorvastatin $10 \mathrm{mg}$ & Perindopril arginin $5 \mathrm{mg}$ & Amlodipin $5 \mathrm{mg}$ \\
\hline Lipertance $20 \mathrm{mg} / 5 \mathrm{mg} / 5 \mathrm{mg}$ & Atorvastatin $20 \mathrm{mg}$ & Perindopril arginin $5 \mathrm{mg}$ & Amlodipin $5 \mathrm{mg}$ \\
\hline Lipertance $20 \mathrm{mg} / 10 \mathrm{mg} / 5 \mathrm{mg}$ & Atorvastatin $20 \mathrm{mg}$ & Perindopril arginin $10 \mathrm{mg}$ & Amlodipin $5 \mathrm{mg}$ \\
\hline Lipertance $20 \mathrm{mg} / 10 \mathrm{mg} / 10 \mathrm{mg}$ & Atorvastatin $20 \mathrm{mg}$ & Perindopril ariginin $10 \mathrm{mg}$ & Amlodipin $10 \mathrm{mg}$ \\
\hline Lipertance $40 \mathrm{mg} / 10 \mathrm{mg} / 10 \mathrm{mg}$ & Atorvastatin $40 \mathrm{mg}$ & Perindopril arginin $10 \mathrm{mg}$ & Amlodipin $10 \mathrm{mg}$ \\
\hline
\end{tabular}


Statiny navíc příznivě ovlivňují prognózu diabetiků, jak ukázala metaanalýza s 18686 pacientů.

Snížení rizika KV onemocnění odpovídá poklesu LDL cholesterolu, jak prokázala metaanalýza 14 randomizovaných studií se statiny, která zahrnovala 90056 pacientů [26]. Další metaanalýza 26 randomizovaných studií se 170000 pacienty z roku 2010 doložila prrínos intenzivního snižování LDL cholesterolu. S každým snížením LDL cholesterolu o $1 \mathrm{mmol} / \mathrm{l}$ dojde $\mathrm{k}$ poklesu rizika $\mathrm{KV}$ onemocnění o $21 \%$ [27]. Poslední publikovaná studie se statiny, HOPE-3, ukázala $25 \%$ pokles mortality z KV příčin a rizika CMP, srdeční zástavy, revaskularizace a srdečního selhání při léčbě rosuvastatinem. Prínos statinů se v této studii jevil jako ještě významnější než kontrola hypertenze. U rizikového nemocného je však třeba léčit všechny rizikové faktory současně.

\section{To nejlepší z medicíny založené na dưkazech pro jednodušší léčbu hypertenze a dyslipidemie}

\section{Body k zapamatování}

- V patogenezi aterosklerózy se uplatňuje interakce mezi aterogenní dyslipidemií a systémem renin-angiotensin (RAS).

- Blokáda RAS a kalciových kanálů se vhodně doplňuje v účincích na funkci endotelu, progresi aterosklerózy a výskyt CMP a komplikací ICHS.

- Kombinace těchto tříd antihypertenziv se statinem dále zvyšuje KV prrínos s poklesem rizik IM až o 53 \%.

Vzájemné synergii perindoprilu, amlodipinu a atorvastatinu v KV prevenci se věnoval prof. Linhart. Hypertenze vede k endoteliální dysfunkci, zvýšení tuhosti cév, progresi a destabilizaci aterosklerózy a následně k aterotrombotickým príhodám, hypertrofii a dysfunkci levé komory, fibrilaci síní a poškození ledvin. Při volbě antihypertenziva je třeba zohlednit účinnost včetně klinických důkazů o vlivu na morbiditu a mortalitu, snášenlivost, ale i metabolickou neutralitu, jednoduchost léčby a možnost kombinované terapie. Kombinace blokátorů RAS a BKK patří mezi doporučované kombinace antihypertenziv [28]. Dưvodem je mimo jiné jejich antidiabetogenní účinek [29] či absence nárůstu tělesné hmotnosti (která byla pozorována u beta-blokátorů) [30]. Existuje také vzájemná souvislost mezi terapeutickým ovlivněním hypertenze a hypercholesterolemie. Koncentrace cholesterolu ovlivňuje denzitu receptorů $A T_{1}$. Vasodilatační účinek $A C E I$ závisí na výchozí koncentraci LDL cholesterolu [31]. ACEI, BKK i statiny příznivě ovlivňuji dysfunkci endotelu [32-34]. Všechny tyto skupiny lékư mají také antiaterogenní účinky: ve statinových studiích byl prokázán vztah mezi koncentrací LDL cholesterolu a objemem ateromového plátu [35], amlodipin vykázal účinek proti progresi plátů [36] a při léčbě perindoprilem byla zjištěna regrese nekalcifikovaných plátů [37]. A konečně nejtvrdší data prokázala, že koncentrace LDL cholesterolu při léčbě koreluje s výskytem KV příhod [38]. ACEI jsou účinnější než BKK při snižování rizika KV příhod a BKK jsou účinnější než ACEl při snižování rizika CMP, vždy nad rámec kontroly TK [39]. Ve studii ACCOMPLISH zkrátila kombinace ACEI s amlodipinem dobu do první KV příhody v porovnání s ACEI a hydrochlorothiazidem o $20 \%$ [40]. Post-hoc analýza studie EUROPA přinesla důkaz, že přidání perindoprilu k BKK sníží celkovou mortalitu o 46 \% [41] a ve studii ASCOT znamenalo přidání perindoprilu a amlodipinu $\mathrm{k}$ atorvastatinu pokles výskytu fatálních i nefatálních IM o $53 \%$ v porovnání s $16 \%$ ve větvi, v níž byl přidán atenolol s thiazidovým diuretikem (obr. 2) [41].

Synergické působení perindoprilu, amlodipinu a atorvastatinu má tedy nejen patofyziologické předpoklady, ale je také klinicky prokázáno v rámci medicíny založené na důkazech.

\section{0 kroků pro život}

Jak vysvětlil prof. Linhart, motto jednoho kroku pro léčbu KV rizika, kterou představuje Lipertance ${ }^{\circledR}$, je doplněno koncepcí 6000 kroků pro život. Tato koncepce vychází z faktu, že chůze je fyzická aktivita účinná v KV preven-

\section{ASCOT 2×2: primární sledovaný ukazatel: nefatální IM a úmrtí na IM}

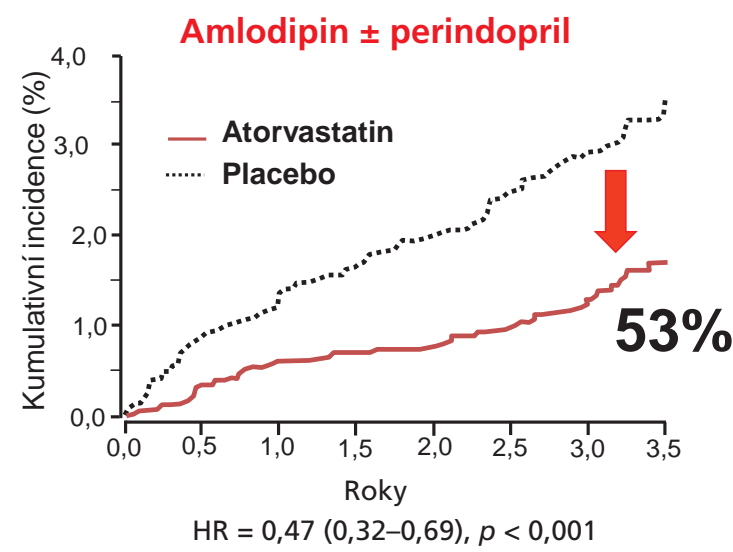

$H R=0,47(0,32-0,69), p<0,001$

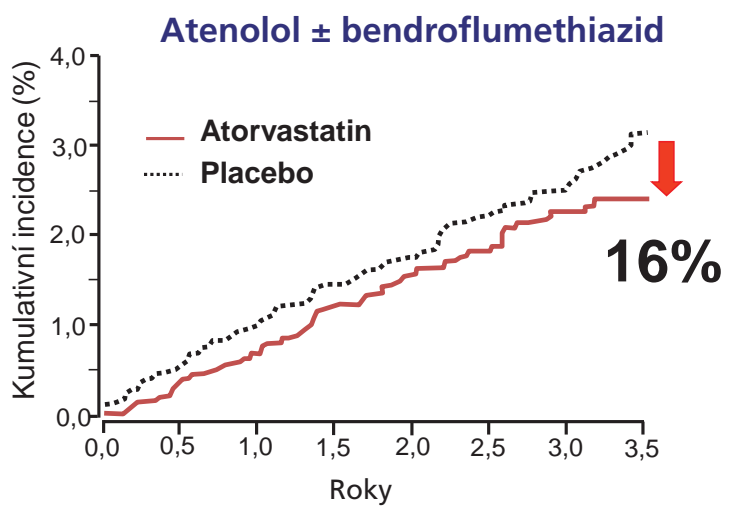

$H R=0,84(0,60-1,17), p=0,30$

Sever et al. Eur Heart J 2006;27:2982-2988. 
ci, která je dostupná všem. Cílová hodnota 10000 kroků denně podle Paula Dudleyho Whitea může být pro řadu pacientů nedosažitelná. $V$ rámci této koncepce byla tedy zjednodušena na doporučení 6000 kroků denně. Odborným garantem programu jeden krok pro léčbu KV rizika, 6000 kroků pro život se stal prof. MUDr. Aleš Linhart, DrSc. Podrobnější informace o programu naleznete na webových stránkách www.6000kroku.cz.

\section{Závěr}

Jak shrnul prof. Souček, hypertenze a dyslipidemie jsou dva časté KV rizikové faktory, které spolu vzájemně souvisejí. Jejich společný výskyt akceleruje KV riziko pacienta, a proto je nutná multifaktoriální léčba. Kombinovaná terapie $v$ podobě fixní kombinace atorvastatinu, perindoprilu a amlodipinu $v$ jediné tabletě jedenkrát denně výrazně zjednodušuje léčbu a je nadějí na zvýšení adherence. Lipertance ${ }^{\circledR}$ nabízí pět dávkových variant pro zahájení léčby i pro pokračující terapii s titrací dávek. Již dnes je zřejmé, že půjde o často využívanou kombinaci v klinické praxi.

Připravila MUDr. Zuzana Zafarová

\section{Literatura}

[1] M. Thoenes, P. Bramlage, S. Zhong, et al., Hypertension control and cardiometabolic risk: a regional perspective, Cardiology Research and Practice 2012 (2012) 925046.

[2] R. Jackson, C.M. Lawes, D.A. Bennett, et al., Treatment with drugs to lower blood pressure and blood cholesterol based on an individual's absolute cardiovascular risk, Lancet 365 (2005) 434-441.

[3] G. Mancia, G. De Backer, A. Dominiczak, et al., 2007 Guidelines for the Management of Arterial Hypertension: The Task Force for the Management of Arterial Hypertension of the European Society of Hypertension (ESH) and of the European Society of Cardiology (ESC). Journal of Hypertension 25 (2007) 11051187.

[4] N.J. Wald, M.R. Law, A strategy to reduce cardiovascular disease by more than $80 \%$, BMJ 326 (2003) 1419-1423.

[5] B.M. Egan, J. Li, S. Qanungo, T.E. Wolfman, Blood pressure and cholesterol control in hypertensive hypercholesterolemic patients: national health and nutrition examination surveys 1988-2010, Circulation 128 (2013) 29-41.

[6] B. Nussbaumerová, H. Rosolová, O. Mayer jr., et al. Residual cardiovascular risk in patients with stable coronary heart disease over the last 16 years (Czech part of the EUROASPIRE I-IV surveys), Cor et Vasa 56 (2014) e98-e104.

[7] B.L. Van Wijk, O.H. Klungel, E.R. Heerdink, A. de Boer, Rate and determinants of 10-year persistence with antihypertensive drugs, Journal of Hypertension 23 (2005) 2101-2107.

[8] F.Z. Kettani, A. Dragomir, R. Côté, et al., Impact of a better adherence to antihypertensive agents on cerebrovascular disease for primary prevention, Stroke 40 (2009) 213-220.

[9] R. Chowdhury, et al. European Heart Journal 34 (2013) 2840-2948.

[10] R.H. Chapman, J.S. Benner, A.A. Petrilla, et al., Predictors of adherence with antihypertensive and lipid-lowering therapy, Archives of Internal Medicine 165 (2005) 1147-1152.

[11] S. Bangalore, G. Kamalakkannan, S. Parkar, F.H. Messerli, Fixed-dose combinations improve medication compliance: a meta-analysis, Journal of Clinical Hypertension 8 (Suppl. A) (2006) P-157 (poster).

[12] R. Plakogiannis, H. Cohen, D. Taft, Effects of morning versus evening administration of atorvastatin in patients with hyperlipidemia, American Journal of Health-System Pharmacy 62 (2005) 2491-2494.
[13] Y. Sirenko, et al. American Journal of Cardiovascular Drugs 2016.

[14] P.S. Sever, B. Dahlöf, N.R. Poulter, et al., Prevention of coronary and stroke events with atorvastatin in hypertensive patients who have average or lower-than-average cholesterol concentrations, in the Anglo-Scandinavian Cardiac Outcomes Trial-Lipid Lowering Arm (ASCOT-LLA): a multicentre randomised controlled trial, Lancet 361 (2003) $1149-1158$.

[15] P. Sever, B. Dahlöf, N. Poulter, et al., Potential synergy between lipid-lowering and blood-pressure-lowering in the Anglo-Scandinavian Cardiac Outcomes Trial, European Heart Journal 27 (2006) 2982-2988.

[16] M. Bertrand, J-J Mourad, Combining perindopril with a calcium channel blocker and a lipid lowering agent significantly decreases mortality: a subgroup analysis of EUROPA, Circulation 128 (22 suppl.) (2013) Abstract A18906.

[17] Randomised trial of cholesterol lowering in 4444 patients with coronary heart disease: the Scandinavian Simvastatin Survival Study (4S), Lancet 344 (1994) 1383-1389.

[18] R. Collins, J. Armitage, S. Parish, et al. MRC/BHF Heart Protection Study of cholesterol-lowering with simvastatin in 5963 people with diabetes: a randomised placebo-controlled trial, Lancet 361 (2003) 2005-2016.

[19] S.M. Haffner, C.M. Alexander, T.J. Cook, et al., Reduced coronary events in simvastatin-treated patients with coronary heart disease and diabetes or impaired fasting glucose levels: subgroup analyses in the Scandinavian Simvastatin Survival Study. Archives of Internal Medicine 159 (1999) 2661-2667.

[20] P. Amarenco, J. Labreuche, P. Lavallée, P.J. Touboul, Statins in stroke prevention and carotid atherosclerosis: systematic review and up-to-date meta-analysis, Stroke 35 (2004) 2902-2909.

[21] J.C. LaRosa, S.M. Grundy, D.D. Waters, et al., Intensive lipid lowering with atorvastatin in patients with stable coronary disease, New England Journal of Medicine 352 (2005) 14251435.

[22] P.S. Phillips, R.H. Haas, S. Bannykh, et al. Statin-associated myopathy with normal creatine kinase levels, Annals of Internal Medicine 137 (2002) 581-585.

[23] D. Rosenbaum, J. Dallongeville, P. Sabouret, E. Bruckert, Discontinuation of statin therapy due to muscular side effects: a survey in real life, Nutrition, Metabolism and Cardiovascular Diseases 23 (2013) 871-875.

[24] D.M. Black, R.G. Bakker-Arkema, J.W. Nawrocki, An overview of the clinical safety profile of atorvastatin (lipitor), a new HMG-CoA reductase inhibitor, Archives of Internal Medicine 158 (1998) 577-584.

[25] D.D. Waters, J.E. Ho, D.A. DeMicco, et al., Predictors of new-onset diabetes in patients treated with atorvastatin: results from 3 large randomized clinical trials, Journal of the American College of Cardiology 57 (2011) 1535-1545.

[26] C. Baigent, A. Keech, P.M. Kearney, et al., Efficacy and safety of cholesterol-lowering treatment: prospective meta-analysis of data from 90,056 participants in 14 randomised trials of statins, Lancet 366 (2005) 1267-1278.

[27] Cholesterol Treatment Trialists' (CTT) Collaboration, Baigent C, Blackwell L, et al., Efficacy and safety of more intensive lowering of LDL cholesterol: a meta-analysis of data from 170,000 participants in 26 randomised trials. Lancet 376 (2010) 1670-1681.

[28] J. Filipovský, J. Widimský jr., J. Ceral, et al., Diagnostické a léčebné postupy u arteriální hypertenze - verze 2012. Doporučení České společnosti pro hypertenzi, Hypertenze \& kardiovaskulární prevence 3 (2012) 1-16.

[29] W.J. Elliott, P.M. Meyer, Incident diabetes in clinical trials of antihypertensive drugs: a network meta-analysis, Lancet 369 (2007) 201-207.

[30] A.M. Sharma, T. Pischon, S. Hardt, et al., Hypothesis: Beta-adrenergic receptor blockers and weight gain: A systematic analysis, Hypertension 37 (2001) 250-254.

[31] B. Pitt, C. Pepine, B.J. O'Neill, et al., Modulation of ACE inhibitor efficacy on coronary endothelial dysfunction by low density lipoprotein cholesterol (abstr). Journal of the American College of Cardiology 29 (Suppl. A) (1997) 70A.

[32] R.C. Webb, et al. Ann Arbor 1992.

[33] X. Zhang, M.R. Kichuk, S. Mital, et al., Amlodipine promotes kinin-mediated nitric oxide production in coronary 
microvessels of failing human hearts, American Journal of Cardiology 84 (1999) 27L-33L.

[34] T.J. Anderson, I.T. Meredith, A.C. Yeung, et al., The effect of cholesterol-lowering and antioxidant therapy on endothelium-dependent coronary vasomotion, New England Journal of Medicine 332 (1995) 488-493.

[35] S. Nissen, E.M. Tuzcu, P. Schoenhagen, et al., Effect of intensive compared with moderate lipid-lowering therapy on progression of coronary atherosclerosis: a randomized controlled trial, JAMA 291 (2004) 1071-1080.

[36] B. Pitt, R.P. Byington, C.D. Furberg, et al., Effect of amlodipine on the progression of atherosclerosis and the occurrence of clinical events. PREVENT Investigators, Circulation 102 (2000) 1503-1510.

[37] N. Bruining, S. de Winter, J.R. Roelandt, et al., Coronary calcium significantly affects quantitative analysis of coronary ultrasound: importance for atherosclerosis progression/ regression studies, Coronary Artery Disease 20 (2009) 409-414.
[38] C.M. Ballantyne, Low-density lipoproteins and risk for coronary artery disease, American Journal of Cardiology 82 (1998) 3Q-12Q.

[39] P. Verdecchia, G. Reboldi, F. Angeli, et al., Angiotensin-converting enzyme inhibitors and calcium channel blockers for coronary heart disease and stroke prevention, Hypertension 46 (2005) 386-392.

[40] K.A. Jamerson, et al., ACCOMPLISH (Avoiding Cardiovascular events through Combination therapy in Patients Living with Systolic Hypertension), American Journal of Hypertension 16 (part 2) (2003) 193A.

[41] M. Bertrand, R. Ferrari, W.J. Remme, et al., Clinical synergy of perindopril and calcium-channel blocker in the prevention of cardiac events and mortality in patients with coronary artery disease. Post hoc analysis of the EUROPA study, American Heart Journal 159 (2010) 795-802.

[42] SPC Lipertance. www.sukl.cz 